\title{
KASZUBSKIE OBRAZY NIE-KASZUBÓW. O KILKU KWESTIACH LITERACKICH Z FAKTOREM POSTZALEŻNOŚCIOWYM
}

\author{
DANIEL KALINOWSKI ${ }^{1}$ \\ (Akademia Pomorska w Słupsku)
}

Słowa kluczowe: Kaszuby, Pomorze, literackie obrazy inności, stereotypy narodowe Key words: Kashubia, Pomerania, literary images of otherness, national stereotypes

\begin{abstract}
Abstrakt: Daniel Kalinowski, KASZUBSKIE OBRAZY NIE-KASZUBÓW. O KILKU KWESTIACH LITERACKICH Z FAKTOREM POSTZALEŻNOŚCIOWYM. „PORÓWNANIA” 20, 2017. T. XX. S. 63-76. ISSN 1733-165X. Artykuł dotyczy podstawowych tendencji w opisach literatury kaszubskojęzycznej, portretującej nie-Kaszubów (Florian Ceynowa, Hieronim Derdowski, Aleksander Majkowski, Jan Rompski). Zasadniczo daje się tutaj wyznaczyć tendencje sympatii i antypatii. Pierwsza pojawia się głównie w stosunku do Polaków, którzy postrzegani są z perspektywy wspólnej walki z germanizacją. Jednakże nie jest to spójna tendencja, ponieważ już u założyciela dyskursu tożsamości kaszubskiej Floriana Ceynowy daje się zauważyć krytykę polskiego modelu społecznego i narodowych cech charakterologicznych. Druga, odwrotna tendencja przedstawiania innych i obcych najsilniej objawia się w literaturze kaszubskiej wobec niemieckiego żywiołu narodowego. Niemal zawsze pełnił on funkcję przykładu przemocy i zła. Pojawiają się wszakże odstępstwa i bywa, że Niemcy opisywani są z szacunkiem i podziwem. Wobec Żydów literatura kaszubska nie zajmuje konsekwentnego stanowiska, co wynika z małej liczebności tej grupy społecznej na Pomorzu.

Obcy/inni przedstawieni w literaturze kaszubskiej są dla Kaszubów zagrożeniem pod względem liczebności, cywilizacji czy kultury. Stąd literaci kaszubscy w swych kreacjach stale przeciwstawiają domowy raj zewnętrznym czynnikom kulturowym. Przybysze spoza Kaszub przynoszą ze sobą chciwość, rozpustę, bezideowość, rzadko kiedy inspirując pozytywnymi cechami. Stają się zatem kolonizatorami Kaszubów, którzy utrzymują władzę w wymiarze państwowym a czasami i religijnym.
\end{abstract}

Abstract: Daniel Kalinowski, KASHUBIAN IMAGES OF NON-KASHUBIANS. ON SOME LITERARY PROBLEMS WITH THE POSTDEPENDENCY FACTOR. “PORÓWNANIA" 20, 2017. Vol. XX. P. 63-76. ISSN 1733-165X. The article focuses on the fundamental trends in the descriptions of Kashubian literature which portrays non-Kashubians (Florian Ceynowa, Henryk Derdowski, Aleksander Majkowski, Jan Rompski). Basically it gives here designate the tendency of sympathy

1 E-mail: danielkalinowski@op.pl 
and antipathy. The first takes place mainly in relation to the Poles who are seen from the perspective of a common struggle against Germanization. However, this is not a consistent trend because already in the discourse of the founder of the Kashubian identity, Florian Ceynowa, criticism of the Polish model of social and national characteristics characterological can be noticed. The second and opposite trend of presenting the other and the foreign is manifested most strongly in the literature Kashubian when including the German national element. It was almost always portrayed as evil and violent. There are, however, exceptions and sometimes the Germans are portrayed with respect and admiration. When it comes to the Jewish, the Kashubian literature does not take a consistent stand because of the small size of this social group in Pomerania.

The foreigners / the others presented in the Kashubian literature are a threat in terms of numbers, civilization or culture for the Kashubians. Hence, Kashubian writers in their creations continuously juxtapose the domestic paradise with the external cultural factors. The newcomers from outside of Kashubia bring with them greed, immorality and a lack of ideological orientation, whereas they rarely inspire positive attributes. Thus, they become colonizers of the Kashubians and hold the state and sometimes even religious power.

\section{Mniejszościowi versus większościowi}

Literatura kaszubska rozumiana jako piśmiennictwo kaszubskojęzyczne to aktywność mająca nieco ponad stusiedemdziesięcioletnią metrykę. Zaistniała ona dzięki uporowi kaszubskiego lekarza, który boleśnie przeszedł lekcję polskiego patriotyzmu - Floriana Ceynowy (Karnowski; Labuda; Pieróg; Kalinowski 2009). Ten etnograf i działacz postawił wypracować koncepcję odrębności kulturowej Kaszubów i konsekwentnie przez całe życie realizował tę ideę. Za jego śladem szły kolejne pokolenia literatów, precyzując swoje postawy wobec wzorców inicjatora kaszubskiego dyskursu tożsamościowego.

Ceynowa pierwszy raz wykreował w rodzimym języku kaszubskie mity fundacyjne oraz sformułował najważniejsze wartości wspólnoty. Wysunął dzięki lekturom kilku kronik historycznych koncepcję o przedchrześcijańskich losach kulturowych, militarnych i społecznych Kaszubów, których ukazywał jako dziedziców plemion Słowiańszczyzny północno-zachodniej. Dzięki ludowemu postrzeganiu Biblii zbudował mit Kaszub jako Ziemi Świętej, wreszcie odwołując się do idei Wiosny Ludów, zaprezentował Kaszubów jako odrębny naród słowiański, mający swoje odmienne od Polaków czy Niemców historię i przyszłość. Również jego przekonania bezpośrednio zawarte $\mathrm{w}$ minirozprawach i tekstach literackich oraz pośrednio umieszczone $\mathrm{w}$ materiałach etnograficznych przynosiły pierwsze kaszubskie samookreślenia wobec innych etnosów, głównie wobec Niemców i Polaków. Poza nimi Ceynowa zaznaczył swoje nastawienie wobec Rosjan, Czechów, Słowaków, Łużyczan oraz Żydów, choć pojawiało się ono dość okazjonalnie, dlatego nie będzie tutaj przedmiotem większych analiz (zob. Bukowski 1947; Cieślak; Treder 1995; Kwaśniewska).

Już wśród wspominanych tutaj dziewiętnastowiecznych zagadnień można zauważyć zachowania i strategie budowania tożsamości kaszubskiej, które w dwu- 
dziestowiecznej tradycji badawczej sformułowane zostały $\mathrm{w}$ ramach dyskursu postkolonialnego i postzależnościowego ${ }^{2}$. Przy czym w odniesieniu do kultury kaszubskiej o postkolonializmie można myśleć na linii niemieckość - kaszubskość, natomiast o postzależności na linii relacji polskość - kaszubskość. Dzieje się tak, ponieważ w pierwszym przy padku intelektualiści kaszubscy od początku opisywania swej relacji z Niemcami czuli się zniewalani oraz wykorzystywani, zaś odmienność językowa i wyznaniowa tylko te uczucia potęgowała, wytwarzając układ kolonizator - kolonizowany. Natomiast w drugim przypadku relacja kulturowa bardziej zasadzała się na stosunku tradycja starsza - młodsza i szlachecka - wiejska, a więc w związkach zależności cywilizacyjno-społecznej. Kaszubi, czując się przez Polaków niedocenieni, podzielali jednak z nimi doświadczenie wspólnego pochodzenia etnicznego (Słowianie), wspólnej religii (katolicyzm) i wspólnej polityki antygermańskiej (szczególnie wobec Kulturkampfu), dopiero od czasów dwudziestolecia międzywojennego zaczęli formułować hasła pobrzmiewające postkolonialnie, przy czym były one bardziej antysanacyjne aniżeli antypolskie. Stąd też bardziej zasadne jest odczytywanie tego typu relacji w świetle metodologii postzależnościowej aniżeli postkolonialnej.

\section{Dialog z Polochem}

Ceynowa napisał dwa dialogi literackie (zob. Ceynowa): wydana w 1850 roku Rozmôva Pôlocha s Kaszebą wraz z Rozmòva Kaszébé z Pòlôchem z 1868 roku tworzy kompozycję literacką z postaciami Kaszuby i Polaka przekonującymi się wzajemnie o wartościach swoich tradycji etnicznych oraz ustalającymi w dyskusjach światopoglądowych najważniejsze wartości tożsamościowe (Bukowski 1950; Kuik-Kalinowska 2009). Trzeba wszakże pamiętać, że utworów tych nie można traktować jako jednoznacznych deklaracji politycznych czy ideowych, ponieważ co chwilę wybija się z nich poetyka dialogu literackiego, a także elementy ludowego postrzegania świata, które służą raczej satyrze niż dyskursowi ideowo-politycznemu.

Tym niemniej warto przywołać choć kilka sygnałów świadczących o tym, jak Ceynowa przedstawiał Polaka, kreowanego nie tyle jako reprezentanta całego narodu, co raczej jako przedstawiciela szlachty. W pierwszym dialogu z 1850 roku Polak wygląda na kogoś zasobnego, godnego szacunku, wobec kogo należy być uprzejmym. Rozmawiający z nim Kaszuba cierpliwie odpowiada na zadawane pytania, nieco usłużnie, ale i drwiąco objaśnia mu, jak ten może zostać Kaszubą. Stale tytułuje go mianem "panie”, ten zaś zwraca się do niego „chłopie”. Kaszuba

2 Tytułem przykładu tej metodologii można przywołać opracowania: Cavanagh; Skórczewski; Bhabha. Część badaczy ustosunkowała się wobec tych propozycji krytycznie. Stąd dyskurs postkolonialny w odniesieniu do warunków kultury polskiej powinien stać się postzależnościowy, jak ukazuje to: np. Gosk 2010. W odniesieniu do literatury kaszubskojęzycznej: Kalinowski 2012. 
zasypuje Polaka mnóstwem opowieści etnograficzno-socjologicznych i kulturowo-historycznych, by tym samym przekonać go do własnego systemu wartości. Jest defensywny, choć jednocześnie ironiczny wobec aktywistycznie nastawionego do rzeczywistości Polaka.

W drugim z dialogów Ceynowy relacja pomiędzy rozmówcami znacząco się zmienia. Teraz Kaszuba prezentuje się jako jednostka dynamiczna, chcąca zmieniać rzeczywistość, natomiast Polak wygląda na zadowolonego z siebie, butnego, a przy tym bardzo wybiórczo wykształconego szlachcica. Specyficzne są powody zachowania Polaka, który przyjmuje za swoją teorię historyczną, jakoby Lechici pochodzili od Chińczyków, a więc od najstarszego na ziemi narodu. Co prawda, jak przyznaje w dialogu Polak, stracili oni w przeciągu wieków wiele azjatyckich cech, lecz pozostali konsekwentni $\mathrm{w}$ unikaniu pracy i w chęci narzucania woli innym narodom. Dla Kaszuby z dialogu Ceynowy tego typu przekonania są dowodem na nieposkromioną dumę. Poza tym w realiach już nie starożytnych, lecz nowożytnych sytuuje kulturę polską jako niewolniczo zależną od wzorców łacińskich i francuskich. Ponadto, stojąc na stanowisku krytyki okcydentalizmu, oskarża polską szlachtę o zaprzepaszczenie dziedzictwa słowiańskiego i o bezkrytyczny liberalizm, który niszczy prawe chrześcijaństwo i wszelką duchowość. Sytuuje to Ceynowę jako intelektualistę, który nie wahał się w języku kaszubskim omawiać kwestii środkowoeuropejskiej tożsamości kulturowej i poruszać zagadnień socjalizmu, liberalizmu, czy ateizmu (zob. Jedlicki; Stefanowska; Tomaszewska).

Dialogi Ceynowy wykorzystują stylistykę literatury popularnej, która sprawia, że argumentacja interlokutorów przybiera postać dosadnego żartu z kontekstem stereotypu regionalnego lub narodowego. Są przy tym nasycone tak polityką, jak żarta$\mathrm{mi}$, tak rozważaniami moralnymi, jak i uciesznymi opowiastkami, wreszcie zarówno przykładami budującymi poczucie wartości, jak i argumentami jawnie tendencyjnymi w swej satyrze czy karykaturze. Z przywołanych tutaj utworów Ceynowy zarysowuje się swoista kłótnia bratnich narodów, które - reprezentowane przez swoich dyskutantów - wzajemnie udowadniają sobie własne ograniczenia. Oczywiście sympatia narracyjna jest po stronie kaszubskiej, to właśnie społeczność pomorska jest depozytariuszką dawnych słowiańskich obyczajów, kultury przodków i zdrowia moralnego. Polacy ze swoim egoizmem stanowym (szlacheckim) i z klerem realizującym zalecenia przeciwnej polskości hierarchii kościelnej zaprzepaszczają możliwość utrzymania własnej, przedchrześcijańskiej jeszcze identyfikacji. Co więcej, przez swój kompleks wielkości szlachta i kler nie dostrzegają możliwości utworzenia wspólnoty z innymi narodami zamieszkującymi ziemie polskie. Dlatego też, jak prowokacyjnie zaznacza Ceynowa w swoim dialogu, możliwa jest interwencja ponadpolskiej i ponadkaszubskiej siły, przewodzącej ruchom panslawistycznym - Rosji. To z jej strony może nastąpić narzucenie zgoła odmiennych praw i porządków.

Tak sformułowane przekonanie pokazuje, że Ceynowa w latach po upadku powstania styczniowego nie szukał łagodnych wobec Polaków środków perswazji, 
aby zauważyli kulturowe racje Kaszubów, ale wybierał inną metodę zdobycia poważania, zwracał się ku Rosji, upatrując w niej protektora rozwoju własnej, kaszubskiej tradycji tożsamościowej (Matusiak; Kościński; Giza; Treder 2001). Przy takim panslawistycznym podejściu mogło mu się wydawać, że uzyska od strony zarówno rosyjskiej, jak i polskiej większy szacunek. Do czasu wyjazdu w 1867 roku na Zjazd Słowiański w Moskwie nie zdawał sobie jednak sprawy, że zainteresowanie rosyjskiego środowiska sprawami kaszubskimi miało swój wymiar polityczny i było formą zwiększania wpływów Rosji nad Bałtykiem. Panslawiści za pomocą jeszcze jednego intelektualisty chcieli zdyskredytować polską działalność patriotyczną. Pozostaje kwestią do rozstrzygnięcia, czy Ceynowa wiedział, jakie reformy zamierzał w polskim szkolnictwie wprowadzać rosyjski badacz kaszubszczyzny Aleksander Hilferding, i czy popierał metody demonizowania kultury polskiej, jakie pojawiały się w środowisku panslawistów (Głębocki 2000; 2006).

\section{Z silniejszym się nie dyskutuje}

W literaturze kaszubskiej, tak zresztą jak i w innych literaturach słowiańskich, poczucie tożsamościowej krzywdy, gorszej ekonomicznie jakości życia oraz istnienia ze słabszą, mniej atrakcyjną kulturą wiejską stale odczuwane było także wobec tradycji niemieckiej (Orłowski; Zernack; Surynt). Traktowanie Słowian i Kaszubów przez Niemców jako głupich wieśniaków, którzy nie umieją się porządnie wysłowić, stało się ciężarem, jaki odczuwali zaniedbani kulturowo w państwie pruskim mieszkańcy części Pomorza (Borzyszkowski 2009). Tworzył się z tego kompleks, który nie miał podstaw jedynie w kreacji artystycznej, lecz wynikał z realnej, społecznej i mentalnościowej sytuacji Kaszubów wobec Niemców. O ile do Polaków Kaszubi mieli żal, iż zapomnieli o ich istnieniu w morzu germańskim, o tyle wobec Niemców w dużo wyraźniejszy sposób zaznaczała się ich niechęć i wrogość, wymieszana z podziwem i fascynacją. Żywioł niemiecki przynosił ze sobą na Kaszuby skuteczną organizację państwową, wojskową i wyznaniową, co samym Kaszubom uświadamiało własne braki w tym względzie (Kalinowski 2014a; 2015). Literaturze pozostawało wówczas przyjąć tyrtejską postawę ideologiczną, zachęcającą do sanacji mentalnościowej i wzrostu uświadomienia narodowego.

Jednym z najbardziej dobitnych przykładów sprzeciwu kaszubskiego autora wobec kultury niemieckiej jest poemat humorystyczny Hieronima Derdowskiego Ò panu Czôrlińsczim co do Pùcka pò sécë jachôł z 1880 roku (Derdowski 2007). Tutaj właśnie odnaleźć możemy jedną z najpopularniejszych autodeklaracji kaszubskich, układających się w tzw. hymn kaszubski, w którym przewija się motyw kaszubsko-niemieckich sporów militarnych. Derdowski włączył Kaszubów w ogólnopolską historię i uczynił ich uczestnikami walk pod Grunwaldem po stronie Jagiełły. Przyporządkował również małopolską legendę o Wandzie, co odrzuciła Niemca, 
do realiów północnych Kaszub i pałacu w Krokowie. Poemat Derdowskiego najdobitniej przedstawia antyniemieckie elementy w kołysance o Krzyżaku-zbójcy, który podstępnie urządził rzeź bezbronnych Kaszubów w Gdańsku w 1308 roku. Wszystkie tego typu partie pozwalają autorowi ukazać występność, chciwość i nieszlachetność żywiołu niemieckiego (Lipski; Kalinowski 2011). Kaszubsko-polsko-słowiańska żywotność, odwaga i humor stały się cechami wyżej cenionymi aniżeli germański materializm, siła i wyrachowanie.

Obraz Niemca pojawia się również w arcypowieści kaszubskiej Aleksandra Majkowskiego Żëcé i przigodë Remusa (Majkowski). Pojawia się tutaj demoniczna postać Smętka-Czernika, która uosabia niemiecką przebiegłość, chciwość i siłę. Raz występuje on jako prawnik umożliwiający sprzedaż kaszubskiej ziemi niemieckim kolonizatorom, innym razem jako pruski policjant poszukujący kaszubsko-polskiego wichrzyciela porządku. Jeszcze w innych momentach wyrasta na biblijnego Goliata albo starożytne bóstwo zła - Arymana. Zawsze jest to figura jednoznacznie Kaszubom wroga, narzucająca im uległość i służebną rolę wykonawców poleceń bogatych ludzi. Niemcy wyglądają w powieści Majkowskiego niczym ekonomiczni zdobywcy, świetni organizatorzy systemu edukacji i prawa, poza tym używają „światowego" języka, który umożliwia im dalszą karierę poza Kaszubami i Pomorzem. Protagoniści kaszubscy obdarzeni wrażliwością i wyobraźnią są niemal zupełnie skazani na przegraną (Kluge; Obracht-Prondzyński; Linkner 2013). Literatura kaszubska staje się w tym momencie - jak w wielu literaturach "słabych" (Bednarczuk, Rudaś-Grodzka; Czapliński) - aktem wezwania do tożsamościowego zrywu, zachętą do wzięcia odwetu na agresorach kulturowych, wyrazem specyficznego mesjańskiego odbioru przeszłości i profetycznej wizji przyszłości.

W kolejnym pokoleniu kaszubskich literatów Jan Rompski w swej liryce ukazał doświadczenie wojenne, w którym to Niemcy stali się inspiratorami sił zła drzemiących w każdym człowieku (Trepczyk, Labuda, Rompski, Bieszk, Grucza, Marszałkowski). Liryki Rompskiego układające się w wojenno-obozową rzeczywistość wskazują na nazizm jako metodę niszczenia drugiego człowieka. W scenach przemocy, patologicznych zachowaniach więźniów i kapo utwory ukazują wielkość cierpienia zadanego Kaszubom i Polakom. Pamięć o masowych mordach w Piaśnicy czy uwięzionych tysiącach ludzi w obozie koncentracyjnym Stutthof wyrażana jest $\mathrm{w}$ wierszach Rompskiego bez kreowania konkretnej postaci oprawcy-Niemca. Pojawiają się za to obrazy posępnego lasu, bezimiennych grobów, ciemne i posępne krajobrazy, w domyśle pozostawiając świadomość, kto wymyślił i realizował rozstrzelania i uwięzienia (Kiedrowski; Drywa; Kuik-Kalinowska 2011).

Z kilku przywołanych przykładów literatury kaszubskiej opisującej swój stosunek do kultury niemieckiej najwyraźniej zarysowują się obrazy wiktimizacji, co jest typowym środkiem wyrazu dla wielu grup mniejszościowych określających swoją pozycję wobec kulturowej czy politycznej większości (Gosk 2011). Jednocześnie jednak czasami manifestuje się wyraz wiary literatów kaszubskich w wyższy porządek 
dziejów, który w końcowym rozliczeniu objawia się tym, że ciemiężeni zostają zdobywcami, zaś zwycięzcy pokonanymi.

\section{Jeszcze mniejsi od mniejszości}

Opisy kultury i społeczności żydowskiej są rzadkim, ale wyrazistym elementem obrazów inności w literaturze kaszubskiej (Boschke-Zielińska; Kalinowski 2016). Nie przedstawiając w tym momencie szczegółowego rejestru literackich ujęć tematu, warto wspomnieć o dwóch postawach narracyjnych kaszubskich autorów, Derdowskiego oraz Majkowskiego. Pierwszy z nich uosabia tendencję antysemicką, wynikającą z zakorzenienia $\mathrm{w}$ pozytywistycznym środowisku konserwatystów oraz ludowego stereotypu Żyda. Drugi reprezentuje tendencję filosemicką, wywodzącą się z neoromantycznego zauroczenia egzotyką oraz innością.

Co do pierwszego zjawiska i reprezentującego go Derdowskiego, należy wspomnieć o jego dwóch poematach humorystycznych: Ò panu Czôrlińsczim co do Pùcka pò sécë jachôł z 1880 roku (Derdowski 2007) oraz Wracanie żydów do Palestyny $i$ wejście do obiecanej ziemi z 1884 roku (Derdowski 1884). Pierwszy z utworów, przedstawiając losy kaszubskiego szlachcica podróżującego po wioskach i miasteczkach Pomorza Wschodniego, jego rozliczne spotkania z ziomkami, sposoby wyprowadzania w pole pruskich urzędników i wyrazy gorących uczuć patriotycznych wobec nieistniejącej na mapach Europy Polski, wplata do nich także motyw żydowski. Żydzi przedstawiani są w utworze jako społeczność handlarzy, rzemieślników, domokrążców, którzy swoim wyglądem, językiem i obyczajami stają się przykładami kulturowej obcości. Już wygląd zewnętrzny kilkunastu postaci żydowskich to zestaw ludowych, pełnych przesądów wyobrażeń czarownika, kłamcy i oszusta. W pierwszej części poematu to właśnie klątwa żydowskiego czapnika powoduje, że kaszubski bohater nie może zrealizować prostego zadania kupna sieci. Głównym zabiegiem „obłaskawiającym” poczucie zagrożenia ze strony Żydów jest u Derdowskiego satyra i karykatura. Grupa handlarzy jadąca w ścisku, ciągnąca zaprzęg czy zmuszona do oddawania czci chrześcijańskim symbolom zostaje za pomocą drwiny i niewybrednego żartu ideowo pokonana. W konsekwencji zdyskredytowana humorem i regionalną swojskością odmienność żydowska przestaje zagrażać poczuciu własnego kaszubskiego "ja”.

W drugiej części utworu Derdowskiego pojawia się postać Bartka, przedstawiana z większą narratorską sympatią, głównie dlatego, że mężczyzna ów nie odznaczał się hałaśliwością i chytrością, ale cichością i skromnością. Żydowi Bartkowi dana jest możliwość bycia zakceptowanym przez Kaszubów współmieszkańcem Pomorza, wszakże pod warunkiem ochrzczenia się. Akt taki niejako się dokonuje, ale w gwałtownej scenie utopienia się bohatera w jeziorze uznawanym za Kaszubów za święte. Wedle świata wartości poematu o panu Czorlińskim żydowska 
inność może zatem zostać przezwyciężona jedynie za sprawą chrztu i odrzucenia żydowskich korzeni religijnych. Tylko taki akt zerwania z kontekstem kulturowym może zdjąć z danej jednostki znamię obcości.

Antyżydowskość czy wręcz antysemityzm jest jeszcze bardziej widoczny w poemacie Derdowskiego Wracanie żydów do Palestyny, który w całości poświęcony został paszkwilanckiemu ukazaniu obcego narodu (Derdowski 1884). Najdobitniej ukazani w utworze baron Rothschild oraz rabin Chajm. To osoby gwałtowne, zawistne i przebiegłe, zaś cała zbiorowość żydowska to rozhisteryzowany, poddany rozkazom rabina tłum, którego głównym celem jest zdobycie dóbr materialnych. Jest to swoiste kaszubskojęzyczne nawiązanie do stereotypu Żyda, obecnego w prawie każdej literaturze Europy Środkowej (Cała 1992; 2012; Tazbir; Żyndul). Każda niemal sfera żydowskiego życia została w poemacie wyśmiana i zdewaluowana. Ceremoniał religijny to kilka szkiców zachowania zewnętrznego, opis stylu bycia sprowadzony został do ukazania rozkrzyczanej, brudnej i biednej hałastry, co w zamierzeniu autora wywołać ma specyficzny czarny humor.

Akcentując literackie fascynacje Derdowskiego, trzeba zauważyć, że w swoich obrazach żydowskiej inności nawiązywał do trzech tradycji: w największym stopniu do kaszubskiej kultury ludowej (satyryczne ujęcia Żydów jako ludzi obcych, biedaków i pogardzanych odmieńców), w stopniu mniejszym do polskiej tradycji literackiej (Żydzi ukazani z pobłażliwością i poczuciem wyższości w polskiej literaturze popularnej, ludowej i jarmarcznej czasów romantyzmu i pozytywizmu) oraz w najmniejszym wymiarze do wpływów niemieckiego kręgu kulturowego (szczególnie humoreski Fritza Reutera, odzwierciedlające ludową obyczajowość i sowizdrzalski humor).

Drugie z klasycznych dzieł literatury kaszubskiej Żëcé i przigodë Remusa Majkowskiego to utwór, w którym opis obcości żydowskiej także staje się ważnym czynnikiem identyfikacyjnym ${ }^{3}$. W wieloaspektowym opisie świata Kaszub, obok charakterystyk samych Kaszubów, Polaków i Niemców, pojawia się także żydowski handlarz - Gaba. Literacki obraz Majkowskiego wyrasta ponad stereotyp i ponad schematyzm folkloru kaszubskiego. Zasadniczą cechą ujęcia postaci Gaby jest szacunek, podziw i rodzaj narracyjnego „ciepła”, jakie roztacza się nad bohaterem.

Największe znaczenie dla kaszubskiej powieści Majkowskiego zasadza się na tym, że Żyd Gabriel oprócz typowego w tamtych czasach handlu guzikami, nićmi, sztućcami czy domowymi drobiazgami rozprowadza również książki. Nie są to przykłady wielkiej literatury, raptem wydawnictwa popularne, adresowane dla ludu, lecz jednak jest to słowo pisane i drukowane (Okopień-Sławińska; Chruściński; Martuszewska). Remus przez lekturę naiwnych romansów, nabożnych opowie-

3 Najpełniejszym literaturoznawczym opracowaniem powieści jest książka zbiorowa: „Życie i przygody Remusa" Aleksandra Majkowskiego. Powieść regionalna czy arcydzieło europejskie (Linkner 1999). Poza tym warto sięgnąć do: Linkner 1996; Borzyszkowski 1997 i wstępów Józefa Borzyszkowskiego, Adeli Kuik-Kalinowskiej i Jerzego Tredera do naukowego wydania: Żëcé i przigodë Remusa (Majkowski). 
ści i różnych prognostyków rozpoczyna swój duchowy progres. Żyd Gaba stał się $\mathrm{w}$ tym procesie ważną figurą przewodnika, doradcy i przyjaciela. Ów obcy nie burzył świata Kaszubów, lecz go wzbogacił, stał się istotnym łącznikiem między pozakaszubskim światem zewnętrznym a wewnętrzną sferą wiejskich osad. Wypełnił zatem tradycyjną w kulturze polskiej rolę żydowskiej społeczności, która łączyła świat chłopów i wsi ze światem szlachty i dworu, lecz odbyło się to bez napięć ekonomicznych czy wzajemnej nieufności.

Obraz Żyda Gabriela został przyporządkowany do galerii pozytywnych postaci z powieści. Majkowski przedstawił tę kreację tylko w pierwszej księdze swojej epopei, lecz wynika to nie tyle z niechęci czy marginalizowania Żydów, a z ich niewielkiej liczebności na przedwojennych Kaszubach (Borzyszkowska-Szewczyk, Pletzing; Kalinowski 2014b). W tej powieści dokonała się ważna zmiana w kaszubskim sposobie oceny obecności Żydów. W Życiu i przygodach Remusa nie ma już konieczności "chrystianizowania” żydowskiego bohatera, jak to się działo w Panu Czorlińskim Derdowskiego. Przejście z „inności” w "swojskość”, „odrębności” w „bliskość” nie musi się odbywać przez ośmieszanie. Narrator powieści dostrzega wspólnotę w losach Kaszubów i Żydów na Pomorzu. W przedstawianych realiach historycznych Kaszubi są bowiem we własnej ojczyźnie zagrożeni germanizacją oraz odczuwają agresywną niemiecką presję kulturową. Wobec niby wysoko cywilizowanych Niemców zarówno Kaszubi, jak i Żydzi wyglądają jak społeczność poddanych i służących, pogardzanych i wyśmiewanych. Majkowski przedstawił zatem żydowską odmienność ubioru, stylu zachowania, języka w lekko tylko ironicznej aurze, bardziej podkreślona została równoległość egzystencji, niedola prześladowania i upośledzenia. Żyd Gabriel to ktoś, kto potrafi w niesprzyjających warunkach życia zachować swój etos, kto potrafi bezinteresownie pomóc i wskazać drogę innym ludziom. Komuś takiemu należy się poważanie, gdyż to wzorzec godności, szlachetności i życiowej mądrości, który warto wziąć pod uwagę.

\section{$* * *$}

W podsumowaniu ograniczonego i wyrywkowego przedstawienia kaszubskich obrazów nie-Kaszubów trzeba zauważyć kilka postaw. Po pierwsze, literatura kaszubska Polaków najczęściej przedstawiała jako słowiańskich braci, którzy sami nie pochodząc z Kaszub, powinni dostrzec związki historyczne między Pomorzem a pozostałymi ziemiami polskimi, a także rozumieć równościowe a nie podległościowe związki w relacji wspólnoty interesów politycznych. W tej relacji niektórzy z kaszubskich literatów tworzyli utwory, w których wyrażali poczucie krzywdy albo niedocenienia swojego regionu, czasami również używali swoistej prowokacji, zapowiadając, że przy braku zainteresowania sprawami kaszubskimi ze strony polskiej skłonni będą nawiązywać bliższe relacje kulturowo-polityczne z Rosją lub Niemcami. 
Po drugie, wobec „silnej” tradycji niemieckiej literatura kaszubska w najbardziej ogólnym wymiarze budowała mechanizmy obronne, które z opóźnieniem reagowały na metodyczną germanizację. Kaszubscy literaci ukazywali zatem negatywne obrazy niemieckich kolonizatorów, pruskich urzędników, niemczących gminę pastorów, czyli ludzi w całościowym wymiarze zaborczych oraz uosabiających wszelkie kulturowe zło. W tym ujęciu Kaszubi postrzegali siebie jako albo jako ofiary agresywnej działalności kultury germańskiej, albo jako heroicznych obrońców wartości rodowych i etnicznych.

Po trzecie, wobec kultury żydowskiej literaci kaszubscy nie przyjęli jednolitego stanowiska. Z jednej strony - jak we wszystkich popularnych i ludowych literaturach europejskich - przedstawiali ich jako zagrożenie dla interesów ekonomicznych i kulturowych, z drugiej jednak potrafiono ukazać bohaterów żydowskich jako jednostki inspirujące i twórcze.

Faktor postzależnościowy rozumiany $w$ ramach tego artykułu jako odkrywanie relacji silny - słaby, większy - mniejszy, dominujący - podległy, w odczytywaniu przykładów literatury kaszubskiej wskazuje na wiele postaw ludzi tej tradycji. Tacy literaci jak Ceynowa, Derdowski, Majkowski czy Rompski (i wielu innych, nieanalizowanych tutaj z braku miejsca), choć odczuwali swoją "mniejszość” (zależność) w liczebności, sile ekonomicznej lub atrakcyjności kulturowej, stale starali się owe negatywne wrażenia przekształcić lub sfunkcjonalizować w odmiennego typu wypowiedzi, które nadawały sens trwaniu przy wartościach rodzimych, rzekomo tylko "słabszych". W tekstach-reakcjach, utworach-wyzwaniach, dziełach-manifestach kaszubskości kreowali pozytywne portrety „naszińców”, na swój sposób odczytywali najdawniejszą i bardziej im bliską historię, mityzowali własną ziemię i miejsce egzystencji, co łącznie miało przydać etnicznej siły w zetknięciu z „silniejszymi" nacjami zamieszkującymi Pomorze i Kaszuby.

\section{BIBLIOGRAFIA}

Bednarczuk, Monika, Rudaś-Grodzka, Monika. „W poszukiwaniu utraconej wielkości”, Teksty Drugie 1-2 (2009). S. 318-334.

Bhabha, Homi K. Miejsca kultury. Przeł. Tomasz Dobrogoszcz. Kraków: Wydawnictwo UJ, 2010.

Borzyszkowska-Szewczyk, Miłosława, Pletzing, Christian. Śladami żydowskimi po Kaszubach. Przewodnik / Judische Spuren in der Kaschubei. Ein Reisehandbuch. Gdańsk - Lübeck: Instytut Kaszubski, Academia Baltica, 2010.

Borzyszkowski, Józef, red. Życie i twórczość Aleksandra Majkowskiego. Wejherowo - Gdańsk: Muzeum Piśmiennictwa i Muzyki Kaszubsko-Pomorskiej - Instytut Kaszubski, 1997.

Borzyszkowski, Józef, red. Niemcy o Kaszubach w XIX wieku. Obraz Kaszubów w pracach G. L. Lorka, W. Seidla i F. Tetznera. Przeł. Magdalena Darska-Łogin, Miłosława Borzyszkowska-Szewczyk, Astrid Popien. Gdańsk: Instytut Kaszubski, 2009. 
Boschke-Zielińska, Anita. „Żydzi w literaturze kaszubskiej”. Kaszubszczyzna w świecie. Red. J. Samp. Wejherowo: Muzeum Piśmiennictwa i Muzyki Kaszubsko-Pomorskiej, 1994. S. 123-137.

Bukowski, Andrzej. Florian Cenowa. Twórca regionalizmu kaszubskiego. Szkic literacki. Gdańsk: Instytut Bałtycki, 1947.

Bukowski, Andrzej. Regionalizm kaszubski. Ruch naukowy, literacki i kulturalny. Zarys monografii historycznej. Poznań: Instytut Zachodni, 1950.

Cała, Alina. Wizerunek Żyda w polskiej kulturze ludowej. Warszawa: Wydawnictwo UW, 1992.

Cała, Alina. Żyd - wróg odwieczny? Antysemityzm w Polsce i jego źródła. Warszawa: Wydawnictwo Nisza, 2012.

Cavanagh, Clare. „Postkolonialna Polska”. Przeł. Tomasz Kunz. Teksty Drugie 2-3 (2003). S. 60-71.

Ceynowa, Florian S. Rozmòwa Pòlôcha z Kaszëbą. Rozmòwa Kaszëbë z Pòlôchã. Oprac. wstęp i przyp. Jerzy Treder. Gdańsk: Instytut Kaszubski, 2007.

Chruściński, Kazimierz. Formy literatury popularnej w Wielkopolsce i na Pomorzu w okresie pozytywizmu. Gdańsk: Uniwersytet Gdański, 1983.

Czapliński, Przemysław. „Resztki utopii. Literatura najnowsza i wymyślanie przyszłości”. Nowe dwudziestolecie (1989-2009). Rozpoznania. Hierarchie. Perspektywy. Red. H. Gosk. Warszawa: Dom Wydawniczy Elipsa, 2010. S. 40-79.

Cieślak, Tadeusz. Sprawa chłopska w poglądach i czynach Floriana Cenowy. Toruń: Instytut Bałtycki, 1952.

Derdowski, Hieronim. Wracanie żydów do Palestyny i wejście do obiecanej ziemi. Toruń: Smulski, 1884.

Derdowski, Hieronim J. Ò panu Czôrlińscim co do Pùcka pò sécë jachôt. Oprac. Jerzy Samp, Jerzy Treder, Eugeniusz Gołąbek. Gdańsk: Instytut Kaszubski, 2007.

Drywa, Danuta. Twórczość obozowa więźniów obozu koncentracyjnego Stutthof. Gdańsk: Muzeum Stutthof, 2010.

Giza, Antoni. „Panslawizm rosyjski XIX wieku a kwestia odrębności kaszubskiej”. V Konferencja Stowińsko-Kaszubska. Red. W. Łysiak. Słupsk: Muzeum Pomorza Środkowego, 1999. S. 139-144.

Głębocki, Henryk. Fatalna sprawa. Kwestia polska w rosyjskiej myśli politycznej (1856-1866). Kraków: Arcana, 2000.

Głębocki, Henryk. Kresy Imperium. Szkice i materiały do dziejów polityki Rosji wobec jej peryferii (XVIII-XXI wiek). Kraków: Arcana, 2006.

Gosk, Hanna. Opowieści „skolonizowanego/kolonizatora”. Wkręgu studiów postzależnościowych nad literatura polską XX i XXI wieku. Kraków: Universitas, 2010.

Gosk, Hanna. „(Nie)obecność opowieści o wstydzie w narracji losu polskiego. Rekonesans”. Kultura po przejściach, osoby z przesztością. Polski dyskurs postzależnościowy - konteksty i perspektywy badawcze. Red. R. Nycz. Kraków: Universitas, 2011. S. 83-86.

Jedlicki, Jerzy. Jakiej cywilizacji Polacy potrzebują. Studia z dziejów idei i wyobraźni XIX wieku. Warszawa: PWN, 1988.

Kalinowski, Daniel. „Spiskowiec, folklorysta i samotnik - Florian Cejnowa a romantyzm”. Adela Kuik-Kalinowska, Daniel Kalinowski. Od Smętka do Stolema. Wokół literatury Kaszub. Gdańsk - Słupsk: Instytut Kaszubski, Wydawnictwo Naukowe AP, 2009. S. 67-85.

Kalinowski, Daniel. „Hymny pomorskie. Polski, niemiecki i kaszubski głos ideologiczny”. Wielkie Pomorze. Tożsamość i wielokulturowość. Red. A. Kuik-Kalinowska, D. Kalinowski. Gdańsk - Słupsk: Instytut Kaszubski, Wydawnictwo Naukowe AP, 2011. S. 119-141. 
Kalinowski, Daniel. „Kaszuby a badania postkolonialne”. Nowy regionalizm w badaniach literackich. Badawczy rekonesans i zarys perspektyw. Red. M. Mikołajczak, E. Rybicka. Kraków: Universitas, 2012. S. 115-134.

Kalinowski, Daniel. „Mity fundacyjne w literaturze kaszubskiej”. Geografia wyobrażona regionu. Literackie figury przestrzeni. Red. D. Kalinowski, M. Mikołajczak, A. Kuik-Kalinowska. Kraków: Universitas, 2014. S. 156-170.

Kalinowski, Daniel. Raptularz kaszubski. Gdańsk: Wydawnictwo ZK-P, 2014. S. 236-246.

Kalinowski, Daniel. „Kaszubskie kompleksy kulturowe (z centrum i prowincją w tle)”. Centra - peryferie w literaturze polskiej XX i XXI wieku. Red. W. Browarny, E. Rybicka, D. Lisak-Gębala. Kraków: Universitas, 2015. S. 259-273.

Kalinowski, Daniel. „Kaszubski portret Żydów. Główne kierunki i techniki”. Żydzi polscy i pomorscy. Studia o ludziach i literaturze. Gdańsk - Słupsk: Instytut Kaszubski, Wydawnictwo Naukowe AP, 2016. S. 287-310.

Karnowski, Jan. Dr Florian Ceynowa. Oprac. i posł. Jerzy Treder. Gdańsk: Czec, 1997.

Kiedrowski, Wojciech. Wyb. i red. Piaśnica oczyma poetów. Gdańsk - Wejherowo: Czec, Urząd Gminy 2001.

Kluge, Friedemann. „Obraz Niemca w powieści kaszubskiej”. Życie i twórczość Aleksandra Majkowskiego.

Red. J. Borzyszkowski. Wejherowo - Gdańsk: Muzeum Piśmiennictwa i Muzyki Kaszubsko-Pomorskiej, Instytut Kaszubski, 1997. S. 147-160.

Kościński, Konstanty. Idea stowiańska na Kaszubach. Szkic historyczny. Poznań: nakładem Autora, 1908.

Kuik-Kalinowska, Adela. „Gorzki dialog, cierpki humor i problemy filozoficzne. O «Rozmôvie Pôlocha s Kaszebą» i «Rozmòvie Kaszébé z Pòlôchem» Floriana Ceynowy”. A. Kuik-Kalinowska, D. Kalinowski. Od Smętka do Stolema. Wokół literatury Kaszub. Gdańsk - Słupsk: Instytut Kaszubski, Wydawnictwo Naukowe AP, 2009. S. 89-110.

Kuik-Kalinowska, Adela. „«Zemja mogił i grobów». Topika tanatyczna w literaturze kaszubskiej”. Tatczëzna. Literackie przestrzenie Kaszub, Słupsk - Gdańsk: Wydawnictwo Naukowe AP, Instytut Kaszubski, 2011. S. 286-292.

Kwaśniewska, Anna. Badania etnograficzne na Kaszubach i Pomorzu Wschodnim w XIX i XX w. Ludzie, instytucje, osiagnięcia badawcze. Gdańsk: Instytut Kaszubski, 2009. S. 47-59.

Labuda, Gerard. „«Sprawa kaszubska» w perspektywie historii”. Kaszubi i ich dzieje. Gdańsk: Czec, 1996. S. 23-40.

Linkner, Tadeusz. Heroiczna biografia Remusa. W świetle mitu i kaszubskich wierzeń. Gdańsk: Czec, 1996.

Linkner, Tadeusz. Red. „Życie i przygody Remusa” Aleksandra Majkowskiego. Powieść regionalna czy arcydzieło europejskie. Słupsk: Wydawnictwo Uczelniane WSP, 1999.

Linkner, Tadeusz. Z literatury Młodokaszubów. Aleksander Majkowski. Studia i szkice. Kościerzyna: Wydawnictwo „Bernardinum”, 2013. S. 56-87.

Lipski, Tadeusz. „O hymnie kaszubskim Hieronima Derdowskiego”. Kościerskie Zeszyty Muzealne 1 (2007). S. 97-107.

Majkowski, Aleksander. Żëcé i przigodë Remusa. Zvjercadło kaszubski. Oprac. i przyp. J. Treder, wstęp: J. Borzyszkowski, A. Kuik-Kalinowska. Gdańsk: Instytut Kaszubski, 2010.

Martuszewska, Anna. „Ta trzecia”. Problemy literatury popularnej. Gdańsk: Wydawnictwo UG, 1997. 
Matusiak, Szymon. „Panslawizm na Kaszubach”. Przegląd Powszechny 11, t. 43 (1894). S. 1-25.

Obracht-Prondzyński, Cezary. „Niemcy widziani oczyma Kaszubów”. W kręgu problematyki kaszubsko-pomorskiej. Gdańsk: Instytut Kaszubski, 2003. S. 37-53.

Okopień-Sławińska, Aleksandra. Red. Formy literatury popularnej. Warszawa: PAN, 1973

Orłowski, Hubert. „Polnische Wirthschaft”. Nowoczesny niemiecki dyskurs o Polsce. Olsztyn: Wspólnota Kulturowa Borussia, 1998.

Pieróg, Ireneusz. Florian Stanistaw Ceynowa. Życie i dziatalność. Toruń: Wydawnictwo Adam Marszałek, 2009.

Skórczewski, Dariusz. „Postkolonialna Polska - projekt (nie)możliwy”. Teksty Drugie 1-2 (2006). S. 100-112.

Stefanowska, Zofia. Strona romantyków. Studia o Norwidzie. Lublin: Towarzystwo Naukowe KUL, 1993.

Surynt, Izabela. „Badania postkolonialne a «Drugi Świat». Niemieckie konstrukcje narodowo-kolonialne XIX wieku", Teksty Drugie 4 (2007). S. 25-46.

Tazbir, Janusz. Protokoty mędrców Syjonu. Autentyk czy falsyfikat? Warszawa: Iskry, 2003.

Tomaszewska, Grażyna. Mickiewicz - Krasiński. O wyobraźni utopijnej i katastroficznej. Gdańsk: Wydawnictwo UG, 2000.

Treder, Jerzy. „O Ceynowie na marginesie dawnych i najnowszych prac”. Rocznik Gdański 2, t. 55 (1995). S. 51-109.

Treder, Jerzy. „Kontakty naukowe Floriana Ceynowy z Rosjanami”. Stownik Floriana Ceynowy. Wejherowo: Muzeum Piśmiennictwo i Muzyki Kaszubsko-Pomorskiej, 2001.

Trepczyk Jan, Labuda Aleksander, Rompski Jan, Bieszk Stefan, Grucza Franciszek, Marszałkowski Feliks. Poezja zrzeszyńców. Oprac. H. Makurat, wstęp J. Borzyszkowski, D. Kalinowski, H. Makurat. Gdańsk: Instytut Kaszubski, 2013. S. 562-566, 634-635.

Zernack, Klaus. Niemcy - Polska. Z dziejów trudnego dialogu historiograficznego. Przeł. Łukasz Musiał, red. H. Olszewski. Poznań: Wydawnictwo Poznańskie, 2006.

Żyndul, Jolanta. Kłamstwo krwi. Legenda mordu rytualnego na ziemiach polskich w XIX i XX wieku. Warszawa: Wydawnictwo Cyklady, 2011. 